\title{
sciendo
}

\section{Statistical model of investment evolution in European Union in the context of blockchain system}

\author{
Mădălina-Gabriela ANGHEL \\ "Artifex" University of Bucharest, Romania \\ madalinagabriela anghel@yahoo.com
}

\author{
Constantin ANGHELACHE \\ The Bucharest University of Economic Studies / "Artifex" University of Bucharest, Romania \\ actincon@yahoo.com \\ Cristian Marian BARBU \\ "Artifex" University of Bucharest, Romania \\ barbu cristianmarian@yahoo.com
}

Gabriel Ștefan DUMBRAVĂ

The Bucharest University of Economic Studies, Romania

stefan.dumbrava@gmail.com

\begin{abstract}
The economic growth of the national economy, within international bodies, as well as in the European Union, is a priority under the present conditions. Capital placement in geographic areas is based on effective opportunity studies. Such an analysis involves access to databases that satisfy the criteria for selecting the place of investment. At the same time, the media interested in attracting national or international investments can take such a decision on the basis of the data that will lead it to the optimal decision. Usually study of the market and the investment fields is insufficient and as such the effectiveness of the project is reduced. Under the very big data base, investors will have the chance to have information that needs to be used in a short time, and such opportunities need to be endowed with ultra-modern information systems. The issue of national and international investment is of utmost interest for any Member State of the European Union. In this respect, major projects will be developed involving as many member countries as possible, provided that everyone has the supremacy (to provide benefits) in a particular project sub-domain. Only specialization can provide the path to a viable and yet prolific economic and scientific cooperation. Through its directives, the European Union pursues both the individual development of each country and, above all, the complex development of the whole of the Union. In the big data era, investments, attracting them or entering into intra-Community economic cooperation provide a much faster course.
\end{abstract}

Keywords: investment, decision, database, information system, economic efficiency.

\section{Introduction}

Many potential benefits of the blockchain system at any level ensure high profitability. Redesigning and automating processes in peer-to-peer networks already provides benefits in the field of international investment, which can be summed up as follows: an extraordinary speed to solve the problem, which involves automation from one end to the other; a low cost 
associated with the transmission of almost infinite amounts of data to huge central facilities and the elimination of costly intermediates. What is currently being achieved through a series of possibilities now clearly results from this blockchain; revenue and efficiency are due to the extraordinarily high productivity of this Blockchain, which has greater effectiveness as the number of operations accessed is greater; the system provides increased security and integrity, trusting those who use it to be a well-polished system with low chances of falling as a system; thus eliminating the bottlenecks that may appear, the existence of an almost perfect system results; privacy is particularly protected because the intermediary can not pass or ignore the rules defined in Blockchain, and thus ensures very high confidentiality; the system also provides a better understanding of the patterns of the processes and opportunities at the bottom that improve them by collecting and analyzing infinitely big data, easily interpreting everything that is happening. Enhance the precision capability of different events that happen, indifferent if negative or positive, is another element that, based on the computational algorithms that can be used, is made available to all who will access and work in the Blockchain system. The IOT model can support itself even after a company retreats or a manufacturer fails. When designed and introduced into the system, interoperability will allow the interconnection of different networks and unleash an enormous number of data and activities that are becoming more and more difficult under other conditions.

All this, in the context of the big data, is the only alternative to future developments in international transactions, especially in the field of investment and international trade.

\section{Literature review}

Anderson and Semmelroth (2015) studied and statistically presented the way in which large data can be used in the analysis of different areas of activity. Anghel et al (2017) studied the role of investment, especially the foreign on the growth of economy. Anghel et al (2016) analysed the role of correct decision on investments. Anghelache (2018) made a deep analyse on the period of ten years since Romania became member of the European Union. Anghelache et al (2015) contrentrated on the FDI model. Blonigen et al (2007), Anghelache and Sacală (2014) analysed the interdependence between business environment and investment. Carkovic and Levine (2005) studied how foreign direct investment accelerates economic growth. Cicak and Soric (2015), Michelis and Monfort (2008) referred to the regional correlation. Pistoresi and Rinaldi (2012) referred to the european map of banks. Popielas (2012) concentrated investments. Stępniak (2015) analyzed european investments. Schnabl (2012) has developed on the transmissible effect for liquidity shocks in the banking system. Wu. X., Zhu et al. (2014) presented HACE theory regarding the Big Data future.

\section{Research methodology, data, results and discussions}

Generally speaking, one can appreciate that the economic development of a state is based on investments that can ensure sustainable development. In this context, taking into account the current large data system, comprehensive and well-correlated models need to be built. Thus, the IOT model is recommended to be used in the big data conditions. By developing these ideas, the authors made an analysis using Romania's economic system in a concrete way. What started out as a click of crypto-initiates quickly transformed into the group of the largest and brightest venture capitalists. Titans in financial services play the role of venture capitalists. Thus, Goldman Sachs, NYSE, Visa, Barkley's, UBS, DeLoitte have made direct 
investments in Start-ups or supported incubators that support new venture capital investments. Pension funds, too, can be directed to capital investment operations and can be converted into definite investment later on. The thing that we should notice is that the financiers still underestimate the potential of Blockchain because their operations are disappearing and are not always easy to regenerate for immediate and palpable incomes. Venture capitalists argue in favor of technology and support institutions that will probably be the Coin Center that can be used by a multitude of people. Banks and financial services are an area in which a radical and rapid change of views will occur. Most financial institutions that have bitterly rejected Bitcoin as a speculative tool, only after studying and pursuing Bitcoin's Blockchain system have thus come to get involved directly.

Before 2015, only a few major financial institutions announced investments in the bigblockchain system. Currently, the Commonwealth Bank of Australia, the Bank of Montreal, Societe Generale, the State Street, BNY Melon, West Fargo, Mizuho Bank, Norde ING, Unicredit, CommerzBank, Macquarie dozens of banks invest in technology and enter into discussions about using this big-blockchain system. Most of the largest banks in the world signed up and formed a partnership with the LYRUS Foundation to launch a project specific

to the banking system. Banks will be included in the discussion on leadership, but the rest of the stakeholders should look at the strong investors at the moment who are trying to introduce and control this ultra-perfect technology as they moved with care and at the beginning of the Internet, which subsequently became within their reach and their game of interests.

\section{Economic and social growth}

Romania achieved different results in the period that passed after January 1,1990 . In the first two decades, that is until 2010, there were increases and decreases imposed by the alignment strategy on the free market. There followed a short period, practically initiated in 2008, but felt in 2009-2011, in which Romania was also affected by the global economic-financial crisis. The indicators calculated for this period of three to four years, showed a major fall, the revival starting in 2012. The calculated indicators, on the basis of which it is possible to appreciate the economic evolution, began to register increases. The same situation was found with regard to the National Bank's foreign reserves. During this time, the national currency was denominated as well, with the Central Bank pursuing and realizing the rapid attracting of the foreign exchange reserves from the population. However, from the estimates made by the specialized institutions it turns out that, at present, the population is about 30 billion euros / dollars. This amount comes from the remittances of the population that emigrated and introduced them in the country in cash, without banking transaction.

The period that has run since 1990 and up to now, although it has marked a significant increase in exports, which have outpaced imports as a growth rate, has permanently recorded a deficit of the foreign trade balance. In this context, net export (export-import) affected the level recorded by the Gross Domestic Product and the other macroeconomic indicators of results.

During the course, Romania had to resort to external loans or to the capitalization of securities on the internal and external market, in order to be able to balance its rising level of spending. Of course, the vast majority of the annual budget deficit went to cover consumption and less for investments. 
We can appreciate that, in fact, Romania's economic growth is based on consumption, which is not in line with the sustainable development strategy. After the accession to the European Union, on January 1, 2007, Romania started on the path of integration. Of course, in the accession documents, Romania has a series of steps that sometimes have not been completed in time. At the same time, not being sufficiently prepared with projects, Romania accessed a low percentage of the Community funds, especially of the non-reimbursable ones. In the presented context it follows that there are few prospects that can put Romania on the track of economic growth based on investments, which provide jobs, structural development of the economy, income growth and, in this way, the standard of living.

The perspective is that of economic recovery through major capital investments, in this regard we consider foreign direct investments, domestic investments and access to community funds. In Romania, the foreign capital of large multinational companies has been developed, and the domestic capital has a still pale contribution.

The Romanian industry needs to enter a development cycle at the level of technology achieved by the developed states of the European Union. On the other hand, at present we cannot speak of a domestic commercial banking system, as long as only two banks (CEC Bank and Eximbank) are still with fully Romanian capital. The other commercial banks in Romania are, in fact, branches of other foreign banks. This state of affairs is reflected in the fact that Romanian investors do not have the opportunity to initiate projects with the support of commercial banks, due to very high interest rates on loans, compared to the lack of interest of banks in attracting liquidity of the population in bank deposits.

During the analyzed period, although the net average wage and the gross average wage have increased, which implies the increase of the incomes and, consequently, of the living conditions, Romania is still far from the average level recorded in this chapter by the other states. States. From a more detailed study, we find that we are in a paradox which, on the one hand, shows that Romania has economic growth based on consumption, in the context in which investments are reduced, but at the same time, as a level of income, we are still far from the average European level.

\section{Growth - objective necessity}

The economic evolution of a country depends on the achievement and maintenance of macrostability. This means that the branches of the national economy operate in a harmonized way, making efficient use of the resources still available to the economy. The strategy applied so far has focused more on alignment with the market economy, neglecting the development of industry and other economic sectors.

In these circumstances, at present, economic growth based on investments or at least through a mixed strategy (investments and consumption), has become an absolute priority.

The transformation of the Romanian economy after 1990 was anarchic and unacceptable in the realities of the production factors it had. Thus, many possibilities were wasted which could at least ensure a balance in the economic evolution, if not a process of macro-stability.

The need for the priority development of some branches of the national economy must also be based on the fact that important projects are being developed in the European Union, but only those states with a specific specialization in one field or another have access. Always, international cooperation, whether intra or extra-community, is based on specialization. This is why we are discussing the evolution of the European Union at two 
speeds, although in reality it is impossible for some countries to access major projects because they no longer have precise specializations.

For the recovery of the national economy, it is necessary that, besides the sustainable development strategy established in Snagov (at present it is less obvious to implement this strategy), to study the possibility of establishing a project (model) of Romania's development on an interval of at least 20-30 years.

If Romania's economic evolution is a priority then it is clear that attracting foreign direct investment, developing domestic capital, attracting community funds, making the best use of natural resources, all of which can create jobs, are major priorities to consider in any strategy. future economic.

\section{Factors with an effect on investment growth}

From the realities mentioned in the preceding paragraphs it follows that the study on the national economy must focus on the fact that there are determinants that must be considered in government strategies. In this direction, it is necessary to prioritize the measures of economic evolution. Thus, at present, Romania has two more - three areas that carefully developed can ensure economic growth. First of all, it is the tourist area that has almost the entire territory of Romania. At the same time, our country can join the line of increasing the contribution of tourism to the formation of the Gross Domestic Product, such as countries like Cyprus, Greece, Bulgaria, the countries of the Iberian Peninsula or other areas of Europe, not to mention other areas of the world.

In the field of tourism, foreign and domestic investments need only be stimulated and this can be achieved through favorable and consistent legislation that will attract investors.

The second area that can be revitalized is agriculture and forestry. When we speak of this field, from the achievements up to 1990, the potential of the soil, but in conditions of superior agrotechnical processing. In this respect, the agricultural subsidies received from the European Union, as well as those granted by the Romanian state, must be used more effectively. You need to support domestic producers who can provide the agri-food production fund for the country's population. Of course, by entering the European Union, the possibility of protecting the domestic producers through import duties disappeared, being necessary the qualitative increase and the production at lower costs in the field of agriculture. In the field of forestry, it is necessary to protect the forest fund, at the same time with intensifying the process of reforestation of the deforested areas. It is also necessary to develop the complementary industry (the production of agricultural machinery and tools, to maintain the high quality level of the producers of fertilized chemicals and plant protection products, the development of irrigation, etc.) that will ensure superior conditions for the production at a lower cost.

Another factor of economic growth is the exploitation and exploitation of natural resources, internally without resorting globally to the realization by foreign investors with the small "advantage" of royalties. There is a need to reassess the national aviation and, on this basis, to develop the research, prospecting and attracting resources of soil and subsoil into the economic circuit.

Romania's economic results must also be based on the quality of the workforce. In this regard, it is necessary to more closely correlate the preparation of labor quotas with the needs of the national economy. At present, it cannot be about professional conversion as long as about 4 million people from Romania work abroad. We are also here in front of a paradox, 
in the sense that, on the one hand, there are no necessary qualified personnel specific to the existing jobs, but we have a huge number of Romanian employees working abroad. Following a closer study, we can appreciate that the European Union directive on the free movement of the person has advantages for Romania. Thus, at the narrowness of the internal labor market, those persons who temporarily emigrated for economic-financial reasons relax the situation of the number of unemployed that could be a shock to the Romanian economy. At the same time, migrants bring in the country and around 30 billion euros (amount established by estimation), which contributes to the growth of the Gross Domestic Product and other indicators of results.

\section{Investing in foreign capital is a priority}

In the ones presented up to this point, I stressed the need for investments that can ensure a sustainable development of Romania.

Increasing investments can be achieved both by encouraging domestic capital and by attracting foreign capital investments.

In terms of attracting foreign investors, two measures are required that can have a positive effect. First of all, it is about granting important and lasting facilities to those who invest in Romania.

It is easy to understand that foreign investment has a number of advantages, of which we mention: the effortless bringing of foreign capital from the country where it is established; bringing cutting-edge technology; reducing the need for investment loans; increasing the income of the employees which creates and an additional basis for obtaining the revenues to the state budget; improving the management of companies; broadening the market for the sale of products made through the efforts of foreign investors, ie the foreign market for export; achievement of major economic objectives; Romania's exit on the external, intra and extra-EU market, with substantial participation.

In the table no. 1 data are presented regarding the registrations of commercial companies with full foreign participation or in cooperation with Romanian investors in the subscribed share capital. The foreign capital was realized by increasing the patrimony of the existing foreign companies or by creating and maturing new companies. Studying the data from the above table, it turns out that by 2009 , foreign investments had a rising trend, after which due to the effects of the economic-financial crisis, they followed a decreasing course. For example, in 2009, the level of foreign investments was 3.52 billion euros, in 20113.33 billion euros, in 20122.86 billion euros, 2.36 billion euros in 2013. As of this year, The recovery of foreign investments is starting to be 3.88 billion euros in 2014, with growth in the coming years.

Regarding the attraction of foreign capital investments, we find that in the territorial profile it is located in Bucharest, Ilfov, Prahova, Timiș, Cluj or Brașov counties. In other counties, such as Tulcea, Vaslui, Teleorman, Gorj or Buzău, it is difficult to talk about foreign investments. In other news, we find that the main foreign investors are from Germany, Holland, Turkey, USA. Hungary and Moldova are countries involved in foreign investments in Romania or participating in joint projects. 
Table 1. Registration of companies with foreign participation in the subscribed share capital, between 1991 and June 2017

\begin{tabular}{|c|c|c|c|c|c|c|c|c|}
\hline & \multirow{2}{*}{\multicolumn{2}{|c|}{$\begin{array}{l}\text { Inmatriculări de societáți } \\
\text { comerciale } \\
\text { Registrations of } \\
\text { commercial companies }\end{array}$}} & \multicolumn{6}{|c|}{$\begin{array}{l}\text { Valoarea capitalului social total subscris exprimat in: } \\
\text { Value of total subscribed social capital expressed in: }\end{array}$} \\
\hline & & & \multicolumn{2}{|c|}{$\begin{array}{l}\text { monedă naţionalâ } \\
\text { national currency }\end{array}$} & \multicolumn{4}{|c|}{$\begin{array}{c}\text { valutå } \\
\text { foreign currency }\end{array}$} \\
\hline & $\begin{array}{r}\text { număr } \\
\text { number }\end{array}$ & $\begin{array}{c}\text { structurâa } \\
\text { structure } \\
-\%-\end{array}$ & $\begin{array}{l}\text { mii lei } \\
\text { lei thou }\end{array}$ & $\begin{array}{r}\text { structurá } \\
\text { structure } \\
-\%\end{array}$ & $\begin{array}{r}\text { mii dolari } \\
\text { SUA } \\
\text { USD thou }\end{array}$ & $\begin{array}{c}\text { structură } \\
\text { structure } \\
-\% \text { - }\end{array}$ & $\begin{array}{r}\text { mi euro } \\
\text { euro } \\
\text { thousand }\end{array}$ & $\begin{array}{c}\text { structură } \\
\text { structure } \\
-\% \text { - }\end{array}$ \\
\hline TOTAL / TOTAL & 212752 & 100,0 & 164455931,9 & 100,0 & 59915215,3 & 100,0 & 45510556,1 & 100,0 \\
\hline 1991 & 5499 & 2,6 & 258165,5 & 0,2 & 1058260,8 & 1,8 & 817975,6 & 1,8 \\
\hline 1992 & 11765 & 5,5 & 65153,0 & * & 573271,2 & 1,0 & 443106,2 & 1,0 \\
\hline 1993 & 10583 & 5,0 & 92793,2 & 0,1 & 417844,8 & 0,7 & 322970,3 & 0,7 \\
\hline 1994 & 11053 & 5,2 & 230535,9 & 0,1 & 881673,3 & 1,5 & 681483,5 & 1,5 \\
\hline 1995 & 3400 & 1,6 & 67893,9 & +) & 237717,0 & 0,4 & 183741,8 & 0,4 \\
\hline 1996 & 3630 & 1,7 & 229256,3 & 0,1 & 573594,2 & 1,0 & 443355,8 & 1,0 \\
\hline 1997 & 5251 & 2,5 & 232229,8 & 0,1 & 359912,8 & 0,6 & 278192,2 & 0,6 \\
\hline 1998 & 8801 & 4,1 & 728612,4 & 0,4 & 755475,3 & 1,3 & 583939,6 & 1,3 \\
\hline 1999 & 7383 & 3,5 & 1214843,7 & 0,7 & 944365,3 & 1,6 & 729940,9 & 1,6 \\
\hline 2000 & 8567 & 4,0 & 1870247,9 & 1,1 & 839143,8 & 1,4 & 648610,6 & 1,4 \\
\hline 2001 & 7175 & 3,4 & 4820820,8 & 2,9 & 1540810,8 & 2,6 & 1190959,4 & 2,6 \\
\hline 2002 & 7518 & 3,5 & 3541822,9 & 2,2 & 1078746,2 & 1,8 & 833809,6 & 1,8 \\
\hline 2003 & 6609 & 3,1 & 4441402,8 & 2,7 & 1288885,0 & 2,1 & 996235,1 & 2,2 \\
\hline 2004 & 10167 & 4,8 & 9040577,5 & 5,5 & 3032218,4 & 5,1 & 2343732,9 & 5,2 \\
\hline 2005 & 11719 & 5,5 & 7173157,1 & 4,4 & 3149681,6 & 5,2 & 2434525,4 & 5,3 \\
\hline 2006 & 12823 & 6,0 & 6646972,2 & 4,0 & 3127314,6 & 5,2 & 2417237,0 & 5,3 \\
\hline 2007 & 15720 & 7,4 & 7737574,2 & 4,7 & 3314201,6 & 5,5 & 2389392,2 & 5,3 \\
\hline 2008 & 12264 & 5,8 & 15034925,8 & 9,2 & 5924852,8 & 9,9 & 3984432,8 & 8,8 \\
\hline 2009 & 6801 & 3,2 & 15303310,6 & 9,3 & 4817293,2 & 8,0 & 3612610,5 & 7,7 \\
\hline 2010 & 6302 & 3,0 & 17430494,7 & 10,6 & 5144560,8 & 8,5 & 3914440,6 & 8,6 \\
\hline 2011 & 6377 & 3,0 & 10190486,1 & 6,2 & 4659785,0 & 7,8 & 3329432,4 & 7,3 \\
\hline 2012 & 6385 & 3,0 & 12704688,6 & 7,7 & 3678762,1 & 6,1 & 2856416,6 & 6,3 \\
\hline 2013 & 6624 & 3,1 & 10428974,1 & 6,3 & 3150281,2 & 5,2 & 2355803,8 & 5,2 \\
\hline 2014 & 6219 & 2,9 & 17241875,9 & 10,5 & 5011953,9 & 8,4 & 3877239,8 & 8,5 \\
\hline 2015 & 5831 & 2,7 & 5521459,6 & 3,4 & 1428513,1 & 2,4 & 1239305,8 & 2,7 \\
\hline 2016 & 5348 & 2,5 & 9030282,9 & 5,5 & 2169253,4 & 3,6 & 1999866,9 & 4,4 \\
\hline 1.I.-30.VI.2017 & 2938 & 1,4 & 3177374,4 & 1,9 & 756843,0 & 1,3 & 701798,0 & 1,5 \\
\hline
\end{tabular}

Source: National Institute of Statistics and ONRC, Statistical Bulletin no. 6/2017.

\section{Foreign direct investments and their role in the European Union}

The foreign direct investments play an important role not only in Romania but also in the other countries of the European Union. Over time, the countries of the European Union have developed objectives based on investments with an intracommunity priority, but also in the non-EU profile.

In the figure no. 1 highlights the increase of capital investments from non-EU countries, between 2009-2014. It is noted that, during the mentioned period, investments within the European Union have increased. The stocks during this period followed an upward course, being in 2014 about EUR 5800 billion in outward non-EU relations and EUR 4500 billion in outward non-EU relations. 


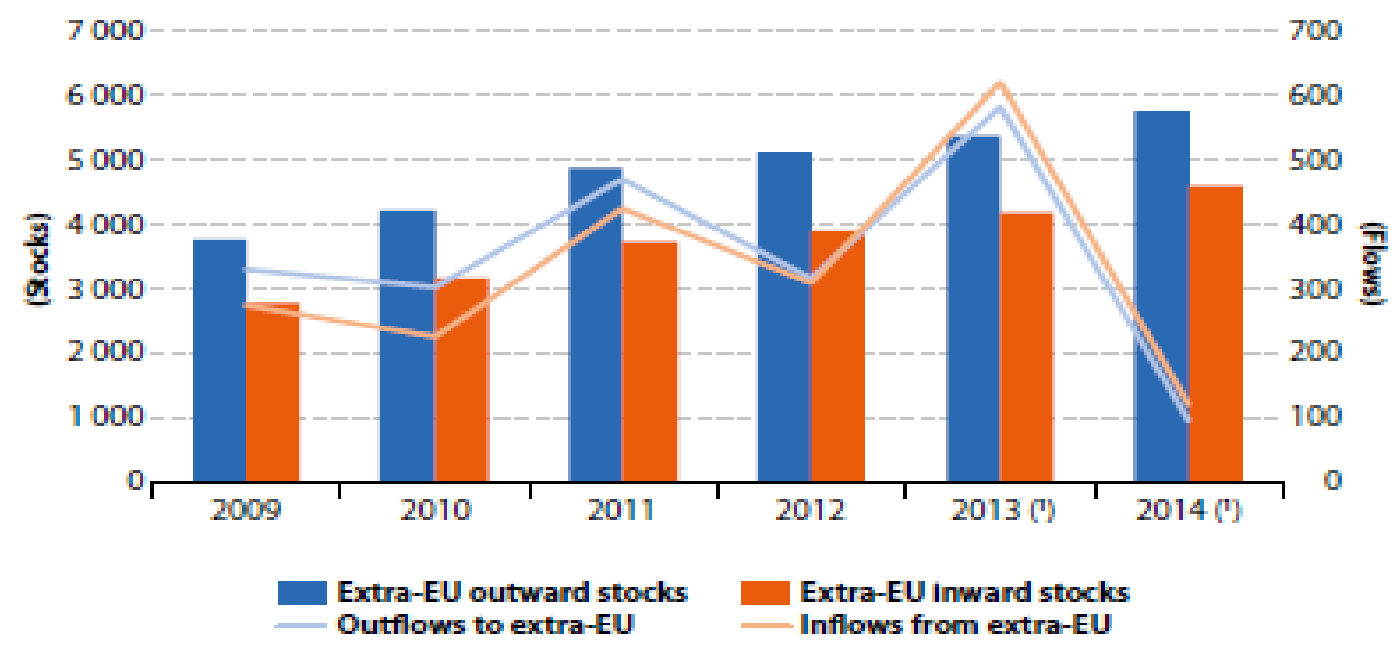

Figure 1. FDI flows and stocks, EU-28, 2009-2014 (billion EUR)

Sursa: Eurostat - Key figures on Europe 2016, pag. 100

In the table no. 2 are presented the first ten non-EU countries with which the European Union as a whole has developed mutual investment relations.

Table 2. Top 10 countries as extra EU-28 partners for FDI positions, EU-28, end 201214 (billion EUR)

\begin{tabular}{|c|c|c|c|c|c|c|c|c|}
\hline & \multicolumn{4}{|c|}{ Outward } & \multicolumn{4}{|c|}{ Inward } \\
\hline & \multicolumn{3}{|c|}{ Value (billion EUR) } & \multirow{2}{*}{$\begin{array}{c}\text { Share }(92) \\
2014\end{array}$} & \multicolumn{3}{|c|}{ Value (billion EUR) } & \multirow{2}{*}{$\begin{array}{l}\text { Share (96) } \\
2014\end{array}$} \\
\hline & 2012 & $2013(1)$ & $2014(1)$ & & 2012 & 2013 (') & $2014(?)$ & \\
\hline Extra EU-28 & 51120 & 5344.4 & 57486 & 1000 & 3905.9 & 4179.7 & 45825 & 100.0 \\
\hline United States & 16278 & 18126 & 19853 & 345 & 1543.9 & 17560 & 1810.8 & 39.5 \\
\hline Switzerland & 6648 & 665.9 & 6303 & 110 & 500.6 & 484.1 & 5024 & 11.1 \\
\hline Brazil & 257.1 & 278.2 & 343.6 & 6.0 & 81.1 & 99.4 & 113.6 & 25 \\
\hline Canada & 247.1 & 234.7 & 274.7 & 4.8 & 135.5 & 135.5 & 165.9 & 3.6 \\
\hline Russis & 199.5 & 1899 & 1715 & 30 & $\pi 3$ & 63.5 & 74.4 & 1.6 \\
\hline China & 120.7 & 124.9 & 1442 & 25 & 27.4 & 223 & 20.7 & 0.5 \\
\hline Mexico & 82.4 & 109.6 & 1192 & 2.1 & 21.4 & 238 & 283 & 0.6 \\
\hline Australia & 141.0 & 126.9 & 1153 & 20 & 30.7 & 24.2 & 2.4 & 0.6 \\
\hline Hong Kong & 132.1 & 113.4 & 1063 & 1.8 & 50.7 & 57.4 & 712 & 1.6 \\
\hline Singapore & 92.6 & 91.9 & 102.9 & 1.8 & 477.7 & 35.7 & 43.8 & 1.0 \\
\hline
\end{tabular}

Sursa: Eurostat - Key figures on Europe 2016, pag. 101

\section{International trade in goods in and out of the European Union}

The development of external relations that we have discussed in the chapter or item on balance of payments is resumed and deepened in this perspective. Thus, the development of the international trade relations of the Member States of the European Union in the period 2005-2015, presented in figure 2, highlights on the total trade balance, imports and exports, that from 2005 to 2010 the balance of the foreign trade of the member countries registered A deficit. There was a slight increase of both imports and exports, but by 2012 the balance balance was still deficient. Starting in 2013, the external balance of trade balance, the trade balance was rising, registering a surplus in 2013, another one slightly, slightly above the equilibrium level (0), and in 2015 provisionally in 2016 saw a significant increase. As far as 
export and import partners are concerned, from and to the countries of the European Union, in 2015 we can mention: they exported $20.7 \%$ to the United States, $9.5 \%$ to China, $4.4 \%$ to Turkey, Russia 4.1\%, Japan 3.2\%, and Norway 2.7\%, 46.9\% of all exports went to partners outside of those mentioned.

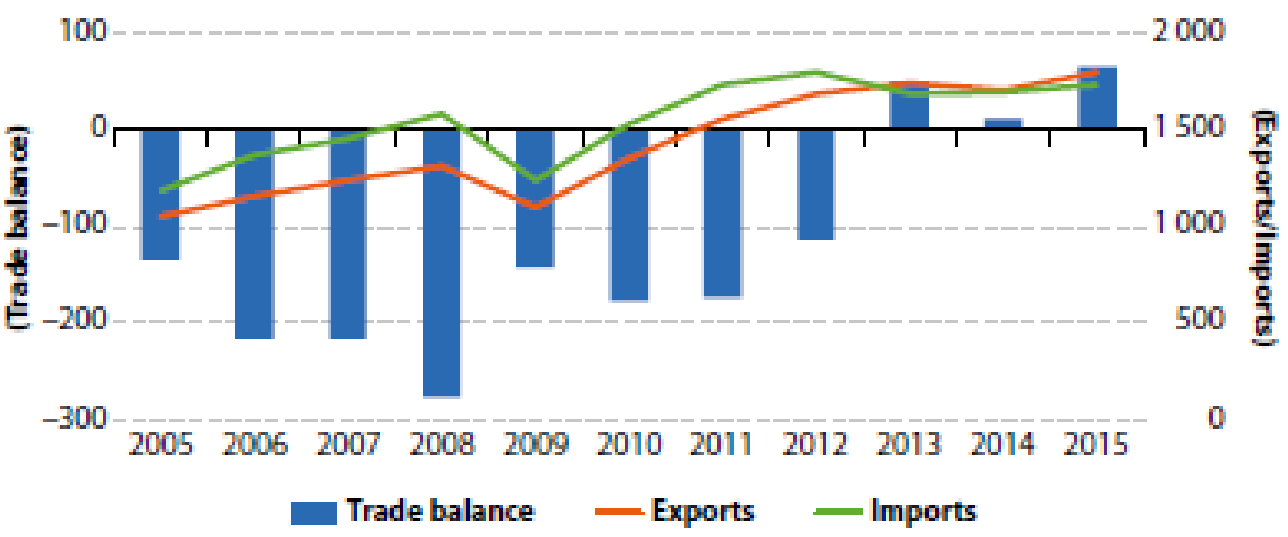

Figure 2. Development of international trade, EU-28, 2005-15 (billion EUR)

Sursa: Eurostat - Key figures on Europe 2016, pag. 105

In terms of imports, the main partner of the EU countries was China without Hong Kong 20.3\%, United States 14.4\%, Russia 7.9\%, Switzerland 5.9\%, Norway 4.3\%, Turkey 3.6 $\%$, Japan $3.5 \%$ and the rest $40.2 \%$ in other states. The same is true of exports of services to and from the countries of the European Union. Here is a brief summary of how EU member countries have evolved, analyzed from the perspective of the main activities and indicators, which are the effect of the strategy of the European Commission, the European Union as a whole.

\section{Investments perspective}

The European Union is still concerned with the development of foreign investments in the member countries, but also with the participation in the achievement of important economic objectives. Against this background, it is necessary for all Member States to find those segments in which they can participate alongside potential investors. At the same time, the European Union, as a whole, wants to place valuable investments in other non-EU countries as well. The main focus is on the states of Asia, Africa and Latin America that have important natural resources. From this point of view, by the eventual completion of Brexit, the European Union is restricted in the context in which the UK still has a great influence among the New Commonwelth countries. At the same time, the United Kingdom will have a privileged position in the development of economic relations, cooperation in the development of projects with the USA. Last but not least, the European Union wants to attract non-EU countries to investment and to initiate joint investments in the member countries of the European Union.

At the level of the European Union, there is concern to intensify economic relations with China, Japan and other countries on the Asian continent.

\section{Conclusions}

From the study presented in this article, a series of conclusions can be drawn. In order to buy, sell or invest, it is necessary to carry out a transaction which, according to all the rules of 
science, imposes three flows: a material flow, ie the material part moving from one legal entity to another, a financial transfer which is even the equivalent of the transaction and, finally, a documentary flow that consists of the attesting documents. All these steps involve time consuming, document closure, and much more. Traditional payment methods do not contain any means of canceling such a transaction.

In the big data era, the bitchin block system ensures that through the nodes and interferences that exist between the fields (transactions and transfers flows) to correct them or, moreover, if the algorithm used is complete, it also includes instructions check - compare, and then the operation resolves very quickly, without error, giving the two people who are dealing. Of course, bitcoin is still a virtual value system that can be used and can be used in the easiest way, especially in the big data context. The rate of $\mathrm{H}$ is the total bitwise processing power. The higher the agreed rate for the entire network, the more difficult it is to find ways of disclosing or resolving issues altogether. There is no operation that is not quality if it fixes itself, providing investment transactions of tremendous speed, with effects that we have discussed in this study.

\section{References}

Anderson, A. \&, Semmelroth, D. (2015). Statistics for Big Data, New Jersey: John Wiley \& Sons. Anghel, M.G., Anghelache, C., Avram, D. \& Burea, D. (2017). Foreign direct investment as an accumulated share of national wealth. Romanian Statistical Review, Supplement, 10, 37-46.

Anghel, M.G., Anghelache, C., Stanciu, E. \& Popovici, M. (2016). The substantiation of the investment decision. Romanian Statistical Review, Supplement, 8, 94-103.

Anghelache, C. (2018). Bilanțul economic al României la 100 de ani, București: Editura Economică.

Anghelache, C., Anghelache, G.V., Niţă, G. \& Sacală, C. (2015). Study on evolution of foreign direct investment flows - model analysis. Romanian Statistical Review Supplement, $10,120-127$.

Anghelache, C. \& Sacală, C. (2014). The Autochtonous Investments and the Business Environment. Romanian Statistical Review Supplement, 10, 81-83.

Blonigen, B., Davies, R. ,Waddell, G. \& Naughton, H. (2007). FDI in space: Spatial autoregressive relationships in foreign direct investment. European Economic Review, 51 (5), 1303-1325.

Carkovic, M. \& Levine, R. (2005). Does foreign direct investment accelerate economic growth. Institute of International Economics Press, Washington DC, 195-221.

Cicak, K. \& Soric, P. (2015). The Interrelationship of FDI and GDP in European Transition Countries. International Journal of Management Science and Business Administration, 1 (4), 41-58.

De Michelis, N. \& Monfort, P. (2008). Some reflections concerning GDP, regional convergence and European cohesion policy. Regional Science Policy \& Practice, 1 (1), 15-22.

Pistoresi, B. \& Rinaldi, A. (2012). Exports, imports and growth, Elsevier in its journal Explorations in Economic History, 49 (2), 241-254.

Popielas, M. (2012). Harmonization Of Investment Services In The European Union - The Example Of Investment Funds. Oeconomia Copernicana, 3 (1), 73-88.

Schnabl, P. (2012). The International Transmission of Bank Liquidity Shocks: Evidence from an Emerging Market. Journal of Finance, 67 (3), 897-932.

Stępniak, C. (2015). Interactive maps as a tool of investment processes support. Collegium of Economic Analysis Annals, 38, 247-258.

Wu. X., Zhu, X., Wu, G.Q. \& Ding, W. (2014). Data mining with big data. IEEE Transactions on Knowledge and Data Engineering, 26 (1), 97 - 107. 